\title{
Seeking consensus regarding the characteristics of expertise and development requirements across five domains of netball coaching in the United Kingdom
}

\author{
Anita Navin ${ }^{1}$ \& Don Vinson ${ }^{2 *}$ \\ ${ }^{1}$ Head of School, Sport and Exercise, University of Gloucestershire, United Kingdom \\ ${ }^{2}$ Principal Lecturer in Sports Coaching Science, University of Worcester, United Kingdom
}

\begin{abstract}
The aim of this study was to develop consensus of opinion from expert netball coaches by exploring prime defining characteristics of, and prime development requirements for, coaching expertise. Forty-eight expert female netball coaches representing five domains were recruited. A four-round Delphi Poll technique was utilised to generate consensus of prime characteristics of expertise and prime development requirements. Distinct characteristics of expertise were identified in each domain. The domain-specific characteristics of expertise dispute the appropriateness of a one-size-fits-all coach development approach such as coaching courses which are not bespoke. Concerning development requirements, the findings demonstrated support for individualised, predominantly informal approaches.
\end{abstract}

Key words: Netball, coaching, expertise, Delphi, coach development

\section{Introduction}

Despite considerable research over the past 35 years, the nature of expert coaching remains contested (Nash, Sproule, \& Horton, 2017). Côté and Gilbert (2009) argued that this lack of conceptual clarity is negatively impacting the development of coaching practice. Furthermore, the lack of a clear understanding of coaching expertise may even be hindering the professionalization of the industry (Taylor \& Garratt, 2010a). Over the years, a number of 'key' areas of

Submitted : 19 June 2019

Revised : 28 January 2020

Accepted : 24 March 2020

Correspondence : d.vinson@worc.ac.uk sports coaching practice have been investigated and have featured, to name a few, coach behaviour (Vinson, Brady, Moreland, \& Judge, 2016), declarative and procedural knowledge (Abraham, Collins, \& Martindale, 2006), the coach-athlete relationship (Jowett, 2017), decision-making (Abraham \& Collins, 2011) and pedagogy (Jones, 2006). Whilst undoubtedly useful components, consensus has not been reached concerning the nature of coaching expertise, although it is widely acknowledged that practitioners operate in highly complex, dynamic, and context-specific environments (Lyle \& Cushion, 2017). Côté and Gilbert (2009, p. 326) have offered what is, to date, arguably the most pervasive and unifying perspective relating to coaching effectiveness and expertise. They suggested 
that only after sustained effectiveness over a number of a years could a coach be considered an expert, defining coaching effectiveness to be:

The consistent application of integrated professional, interpersonal and intrapersonal knowledge to improve athletes' competence, confidence, connection and character in specific coaching contexts.

It is evident from this definition that considerable investigation into specific coaching contexts is required to understand the nature of expertise within specific domains. Netball represents one such specific domain and is one of the most popular sports for females in the UK with around 1.4 million participants annually (Sport England, 2016a). Additionally, England Netball, the UK National Governing Body, reported 13,000 new coaches had qualified since 2008 and published ambitious targets to enhance the number of practitioners delivering on a weekly basis by 2021 (England Netball, 2018). Despite this, research into the netball coaching context is incredibly scarce and there has been no research to date considering coaching expertise in netball. The lack of understanding of netball coaching domains in the UK, coupled with the substantial growth in the number of coaches targeted by England Netball, demonstrates the need to generate understanding of the nature and development of coaching expertise. The aim of this study was to explore and develop a consensus of opinion from expert netball coaches drawn from the range of coaching domains apparent within UK netball by exploring the prime defining characteristics of, and the prime development requirements for, coaching expertise.

\section{Netball coaching in the United Kingdom}

England Netball (2018) identified coaches within the sport to be working across six domains, namely, (i) Children, (ii) Adult participation, (iii) Sustaining participation, (iv) Performance development, (v) Adult performance and (vi) High-performance (elite). Following this structure, Children's coaches would primarily deliver to those aged 11 and below, typically in schools and clubs. Sustaining participation coaches would also usually work in schools and clubs but with those aged typically 11-19. Adult participation coaches would deliver to those over 18 and might run recreationally-focussed programmes such as Back to Netball (see Cronin, Walsh, Quayle, Whittaker, \& Whitehead, 2018) or Walking Netball. Performance development coaches work with under-18 athletes who have been selected for the performance pathway. Coaches will work with these athletes in either county regional or national academy structures. Adult performance coaches would work with those aged 18+ who play in the Regional and Premier leagues. High-performance (elite) coaches deliver to athletes selected for Superleague (i.e. semi-professional) squads or international competition. Coaches in this context operate in a highly competitive and intense environment where World Ranking and win/loss records are pressing concerns. The increase in media coverage for Netball through television and other social media has placed an added pressure on coaches operating in this domain thus further reinforcing the need to explore the contemporary characteristics of coaching expertise in netball (English, Calder, Pearce, \& Kirby, 2019).

\section{Characteristics of sports coaching expertise}

Investigations into sports coaching expertise have fallen behind other domains (Nash, Martindale, Collins, \& Martindale, 2012); in fact, only a very small number of studies addressing this topic have been published (Schempp, McCullick, \& Mason, 2006). Research drawn primarily from the field of cognitive psychology has proposed a number of key features of expert practice and has suggested, for example, that experts process a range of sensory data and recall information more quickly than novices, are more adaptable and take deeper meanings from cues (Nash et al., 2012). Nash 
et al. (2012) outlined criteria for identifying expertise in sport coaching which included declarative knowledge, the ability to work independently, the capacity to produce novel and innovative solutions, a lifelong approach to learning, the ability to engage in self-reflection, managing a complex planning process and the ability to utilise perceptual skills, mental models and routines. Additionally, Vergeer and Lyle (2009) argued that effective decision-making was an integral component of expertise by demonstrating the difference between novice and experienced coaches in this regard. Lyle and Vergeer (2013) proposed that a linear relationship existed between the experience and expertise of the coach and their ability to move away from superficial characteristics. Coaches possessing six to ten years of experience considered a range of factors impacting on the athlete's performance and demonstrated the cognitive capacity to engage in a more detailed presentation of performance issues. The novice or less experienced coach operated in a more haphazard working environment and did not have the capacity to integrate information from a range of sources logically (Vergeer \& Lyle, 2009). In attempt to better understand the whole spectrum of procedural and declarative knowledge required, Abraham et al. (2006) sought the consensus of 16 expert coaches who identified a wide range of bioscientific 'ologies', sport-specific understanding and advanced pedagogic practice. Whilst acknowledging the usefulness of this framework as a broad starting point, Cushion (2018) suggested the findings, along with most other research in this field, over-simplified the acquisition of expertise and failed to consider the potential for institutionalisation by so categorically defining expert coach knowledge and behaviour.

The majority of the studies discussed thus far have focused on performance coaching domains; very little research has been conducted into the characteristics of expertise within the children's, participation-focussed and talent development domains. Nonetheless, there is a considerable volume of research which has discussed the nature of quality coaching in such settings. For example, Gould and Carson (2004) argued that ensuring young athletes experienced positive, enjoyable, sporting environments was not only crucial for recreational youth settings but also beneficial for those athletes seeking to become high-performance athletes. Other features of quality coaching reported in such domains have included the praising of effort (Allen \& Hodge, 2006), facilitating game-like, context-rich, environments (Light, 2017) and seeking athletes' input through carefully structured questioning (Harvey, Cope, \& Jones, 2016). Taken together, these studies affirm the importance of prosocial behaviours and positive learning environments in order to facilitate Positive Youth Development (PYD) (Allan, Turnnidge, \& Côté, 2017; Bruner, Eys, Wilson, \& Côté, 2014).

These discussions have influenced how sports coaching expertise has been defined and, subsequently, how the inclusion criteria for studies in this area have been shaped. In adopting a broad disciplinary perspective, Abraham et al. (2006, p. 552) identified the following inclusion for their study which recruited expert sports coaches through peer identification "(a) recognised as being expert coaches; (b) a consistent use of a critical thinking approach; (c) their roles as mentors to developing coaches; (d) currently working with both elite and developmental athletes". These inclusion criteria have strongly informed that used in the present study. Furthermore, the criteria relating to mentoring and multi-context working, also highlight the importance of considering the development requirements of sports coaches in order to more systematically understand how such expertise is acquired.

\section{Development requirements of expert sports coaches}

Whilst there is an extensive and ever-growing literature pertaining to coach learning, very few studies have systematically and specifically focussed on the requirements for developing expertise. The coach learning literature draws on a broad range of theoretical 
perspectives. The present study draws on two frameworks which have featured prominently in coach learning research and which are particularly well-placed to help explain the development requirements leading to sports coaching expertise.

The first framework, presented by Werthner and Trudel (2006), supposes there to be three learning situations - mediated, unmediated and internal. Mediated learning situations represent occasions when the coach in question has not selected the material to be learned and so is controlled by others. Typically, such learning situations might be organised and certificated coaching courses. Such formal provision has received substantial criticism over a number of years for failing to recognise the needs of individual learners and for being conducted out of context (Mallett, Trudel, Lyle, \& Rynne, 2009; Piggott, 2012). Contrastingly, Werthner and Trudel (2009) argued for the importance of coaching courses, and also for mentoring and interaction with other coaches as key to learning. They identified five key themes pertaining to the development pathways, namely a) previous playing experiences, b) formal education, c) coaching workshops and clinics, d) mentoring and e) an enduring thinking state. Nevertheless, Nash et al. (2012, p. 993) argued that organised coach education in the UK does not clearly delineate expertise from experience and further stated "it is commonly accepted (although more recently challenged) that expertise in any domain takes a minimum of ten years to develop" - a statement broadly supported by the findings of Erickson, Côté, and Fraser-Thomas (2007). Unmediated learning situations represent occasions when the coach decides both the information and source (e.g. colleagues, books, websites). Stoszkowski and Collins (2016) reported that the majority of coaches favour such informal, and preferably social, learning mechanisms. Finally, internal learning does not require new material but requires the reorganisation of what the coach already knows through reflective processes as advocated, for example, by
Schön (1987) and Moon (2004).

The second framework underpinning the present study concerns the third iteration of Wenger-Trayner and Wenger-Trayner's (2015) Social Learning Theory - that of Landscapes of Practice (LoP). This third iteration represents the evolution of the theories of Situated Learning (Lave \& Wenger, 1991) and Communities of Practice (CoP) (Wenger, 1999). CoPs are groups of people who are collaboratively learning by journeying through common life experiences (Wenger, 1999). In the most recent work, the learning theory has evolved to a consideration of the multi-layered CoPs in which most professionals operate - termed LoPs. Wenger-Trayner and Wenger-Trayner (2015) proposed that the boundaries between the complex system of CoPs represent the 'knowledgeability' of an industry, thus reinforcing the belief that learning is much more than the mere acquisition of information. The majority of sports coaching research utilizing the lens of CoPs has viewed the concept relatively favourably in terms of its usefulness as a development requirement for sports coaches, but also in the potential to advance our understanding of how sports coaches learn (Culver \& Trudel, 2008). Due to the relative recent publication of the LoP framework, few studies utilizing this underpinning have been published although the small number of studies which have been conducted have supported its usefulness. Indeed, Bertram and Gilbert (2011) proposed three factors they considered to be crucial for coach learning, namely (i) coach commitment to continuous interaction with one another, (ii) coach passion about and dedication to improving knowledge and expertise, (iii) Jointly developing solutions. The three 'learning situations' and LoP framework will underpin the analysis of the development requirements of coaching expertise in netball as we seek to establish a consensus on how to facilitate identified characteristics of expertise across the various coaching domains in netball in the UK. 


\section{Methods}

Forty eight expert female netball coaches were recruited via convenience and snowball sampling through the professional network of the first author. Three inclusion criteria comprising (i) currently coaching in one of the six participant domains, (ii) identification as an expert by their peer group or by the National Governing Body (NGB), (iii) the capacity to engage participants over a sustained period of time or be instrumental in the progression of talented players were deployed following the precedent of Abraham et al. (2006) and the guidance of H. A. Robertson and MacKinnon (2002). In addition, the number of years coaching experience within their designated domain was considered as part of the sampling process with the target figure of 10 years used as a guide, but not an exclusionary cut-off. Coaches with less than 10 years of experience but meeting the inclusion criteria were not automatically excluded although additional scrutiny was placed on how they met the three principal inclusion criteria (for example, if the NGB was particularly adamant about their expertise, the coach was included). The 48 coaches had amassed an average of $11.24( \pm 8.32)$ years of coaching experience. The 48 coaches represented six coaching domains relatively evenly albeit requiring the merging of the adult performance and high-performance (elite) domains in order to amass a credible sample (Children, $n=11$; Adult participation, $n=9$; Sustaining participation, $n=8$; Performance development, $n=12$; High-performance (elite), $n=8$ ).

A four-round Delphi Poll technique was utilised to explore the opinions of expert coaches within the netball context. The Delphi Poll technique has been established as an effective way of gathering the consensus of expert practitioners and has been used extensively in health and social sciences (Keeney, Hasson, \& McKenna, 2001) and increasingly in sports medicine (e.g. Reneker, Clay Moughiman, \& Cook, 2014; S. Robertson, Kremer, Aisbett, Tran, \& Cerin, 2017). To date, only Morley,
Morgan, McKenna, and Nicholls (2014) have utilised this approach in the sports coaching context, investigating coaches' and players' perceptions of the developmental contexts in one academy at a professional football club. Morley et al. (2014) found the Delphi approach to be useful and appropriate for the sports coaching context in order to develop consensus surrounding talent identification and development issues. The present study received institutional ethical approval.

Round one: Participants received an online questionnaire featuring two open-ended questions: (i) What are the characteristics of expertise for a coach within [defined participant context e.g. the children's coaching domain]? (ii) When, where and how does this expertise develop? A content analysis (Scanlan, Ravizza, \& Stein, 1989) of the responses was conducted comprising four stages. Firstly, tags were created which identified meaningful units of information. Subsequently, tags with similar meanings were grouped together and were placed into first order themes. Thirdly, second order themes were generated by further contrasting and comparing the themes identified in the previous step. This process followed the three characteristics of categorisation outlined by J. A. Smith (2004) namely 1) coding experience, 2) inductive inference and 3) similarity. Finally, general dimensions were identified when no new categories could be established and so the content analysis was concluded (Côté, Salmela, Baria, \& Russell, 1993). Each tag was assigned to the corresponding category.

Round two: Online questionnaires were devised based on the statements generated in the first round using the participants' phraseology wherever possible. Firstly, a questionnaire to explore the defining characteristics of expertise was constructed; for example, a characteristic of expertise was the ability to 'progress skills at varying rates'. Secondly, a questionnaire exploring the development requirements was also devised; for example, a development requirement was 'by gaining coaching qualifications'. 
Following the procedures advocated by Nojima, Tomikawa, Makabe, and Snyder (2003), a five-point Likert scale was applied $(1=$ not at all relevant, very little relevance, somewhat relevant, quite relevant, $5=$ very relevant) for participants to rate each item. Items with a mean score of $\geq 3.75$ were tentatively classified as either prime defining characteristic of expertise or prime development requirements respectively. Subsequently the questionnaires were revised to include only the items achieving a mean score of $\geq 3.75$.

Round three: Revised online questionnaires were completed by the participants utilising a four-point Likert scale thus removing the mid-point response. Items receiving agreement (i.e. Likert responses of 3 or 4 ) by $\geq 51 \%$ of respondents were retained (Nojima et al., 2003).

Round four: Participants rated their level of agreement for each item using a four-point Likert scale on a final revised online questionnaire. The items were then ranked by mean score with the number 1 item receiving the strongest support. Participants were also asked to add any additional comments or suggestions they might have via an open text box at the end of the questionnaire (this box was included at the end of each of the four rounds).

Through each round, descriptive statistics of Mean, Standard Deviation and item rank are used to select and order the responses; this is consistent with previous research in sport (Morley et al., 2014) and also in other fields such as nursing (Nojima et al., 2003) and business (Giannarou \& Zervas, 2014). Most rounds were completed by all of the participants in that domain; on three occasions across the study one participant did not respond within one of the rounds.

\section{Results}

Table 1 outlines the number of items representing the characteristics of expertise and development requirements for each coaching domain. The number of characteristics of expertise ranged from 16-34 although four of the five domains featured between 29-34 items with the Adult participation domain $(n=$ 16) notably lower than the other four. The number of development requirements identified ranged from 5-11 and represented a steady increase from the Children's coaching domain through to High-performance. Seven major categories were identified to represent the themes relating to the characteristics of expertise and which span the five domains, namely i) wider sport knowledge, ii) practice and environmental design, iii) athlete-centred coaching, iv) management and organisation, v) coach-athlete relationships, vi) growth mind set, and vii) character. The key findings from the four stage Delphi process comprising the characteristics of expertise and development requirements from each of the domains will now be presented in turn.

Table 1. Total number of items representing characteristics of expertise and development requirements in each coaching domain

\begin{tabular}{ccc}
\hline \hline Coaching domain & $\begin{array}{c}\text { Characteristics of } \\
\text { expertise }\end{array}$ & $\begin{array}{c}\text { Development } \\
\text { requirements }\end{array}$ \\
\hline Children's coaching & 33 & 5 \\
Adult participation & 16 & 7 \\
$\quad$ Sustaining \\
participation & 34 & 10 \\
$\begin{array}{c}\text { Performance } \\
\text { development }\end{array}$ & 29 & 10 \\
$\begin{array}{c}\text { High performance } \\
\text { (elite) }\end{array}$ & 33 & 11 \\
\hline
\end{tabular}

\section{Children's coaching}

Round one elicited 88 items relating to the characteristics of expertise $(n=56)$ and the development requirements $(n=32)$ which were subsequently presented in round two. In round two, all 56 characteristics of expertise were retained, as were 21 of the 32 items relating to the development requirements having achieved a mean rating of $\geq 3.75$. In round three, 33 of the 56 characteristics of expertise items obtained $\geq 51 \%$ score, yet only five of the 21 development 
requirements were similarly retained. The items and rank order established through round four, are presented in Table 2.

Table 2. Prime defining characteristics of coaching expertise for the Children's domain

\begin{tabular}{|c|c|c|c|c|}
\hline $\begin{array}{c}\text { Item } \\
\text { number }\end{array}$ & Characteristic of expertise $(n=33)$ & Mean & $\mathrm{SD}$ & Rank \\
\hline \multicolumn{5}{|c|}{ Practice and environmental design } \\
\hline 1 & Uses game-like situations & 3.43 & 0.50 & 19 \\
\hline 2 & Knowledge of corrective measures for skills & 3.29 & 0.45 & 25 \\
\hline \multirow[t]{2}{*}{3} & Can condition activities & 3.14 & 0.35 & 30 \\
\hline & Athlete-centred coaching & & & \\
\hline 4 & Will develop confidence and self-esteem & 4.00 & 0.00 & 1 \\
\hline 5 & Promotes engagement and fun & 3.86 & 0.35 & 3 \\
\hline 6 & Promotes decision-making & 3.71 & 0.45 & 8 \\
\hline 7 & Promotes the involvement of everyone & 3.57 & 0.50 & 13 \\
\hline 8 & Promotes self-reflection & 3.57 & 0.50 & 13 \\
\hline 9 & Can personalise learning & 3.43 & 0.50 & 19 \\
\hline 10 & Is child-centred & 3.43 & 0.50 & 19 \\
\hline \multirow[t]{2}{*}{11} & Promotes self-discovery & 3.29 & 0.45 & 25 \\
\hline & Management and organisation & & & \\
\hline 12 & Uses praise and positive reinforcement & 4.00 & 0.00 & 1 \\
\hline 13 & Will praise effort and success & 3.86 & 0.35 & 3 \\
\hline 14 & Uses positive behaviour management & 3.86 & 0.35 & 3 \\
\hline 15 & Develops rapport not friendship & 3.86 & 0.35 & 3 \\
\hline 16 & Promotes a safe environment & 3.71 & 0.45 & 8 \\
\hline 17 & Effective in giving instructions & 3.57 & 0.50 & 13 \\
\hline 18 & Promotes open-ended questioning & 3.43 & 0.50 & 19 \\
\hline 19 & Uses appropriate grouping strategies & 3.29 & 0.70 & 29 \\
\hline 20 & Can build-up skills from the basic level & 3.29 & 0.45 & 25 \\
\hline 21 & Can progress skills at varying rates & 3.14 & 0.64 & 31 \\
\hline 22 & Will work with a supporting coach & 3.14 & 0.64 & 31 \\
\hline \multirow[t]{2}{*}{23} & Session planning & 3.00 & 0.00 & 33 \\
\hline & Coach-athlete relationship & & & \\
\hline 24 & Is approachable & 3.57 & 0.50 & 13 \\
\hline 25 & Can set appropriate boundaries & 3.43 & 0.73 & 24 \\
\hline \multirow[t]{2}{*}{26} & Will commit time and effort & 3.29 & 0.45 & 25 \\
\hline & Character & & & \\
\hline 27 & Portrays a positive image & 3.86 & 0.35 & 3 \\
\hline 28 & Is fair & 3.71 & 0.45 & 8 \\
\hline 29 & Is consistent with behaviour & 3.71 & 0.45 & 8 \\
\hline 30 & Can motivate young participants & 3.71 & 0.45 & 8 \\
\hline 31 & Is inspirational & 3.57 & 0.50 & 13 \\
\hline 32 & Is patient & 3.57 & 0.50 & 13 \\
\hline 33 & Is a good leader & 3.43 & 0.50 & 19 \\
\hline
\end{tabular}

Of notable importance, and ranked highest, were the factors associated with promoting and building confidence and self-esteem. The ability to praise effort and success along with the use of reinforcement was highlighted as a predominant feature of the expert characteristics of a children's coach. The ability to promote engagement and fun, develop rapport and use positive behaviour management strategies were also highly ranked. 'Portraying a positive image' and the notion of being fair were the highest ranked characteristics within the Character category. 'Self-reflection' and 'being open-minded' achieved the highest ranking within the development of expertise requirements (see Table 3).

Table 3. Prime development requirements for the Children's domain

\begin{tabular}{cclccc}
\hline \hline $\begin{array}{c}\text { Item } \\
\text { no. }\end{array}$ & $\begin{array}{c}\text { Form of } \\
\text { Learning }\end{array}$ & $\begin{array}{c}\text { Development requirement } \\
(\mathrm{n}=5)\end{array}$ & Mean & SD & Rank \\
\hline 1 & Unmediated & Self-reflection & 3.86 & 0.35 & 1 \\
2 & & Open discussion with others & 3.57 & 0.50 & 4 \\
3 & Internal & Being open-minded & 3.86 & 0.35 & 1 \\
4 & & Knowledge of self and areas & 3.71 & 0.45 & 3 \\
& & & & \\
5 & for development & 3.43 & 0.50 & 5 \\
\hline \hline
\end{tabular}

\section{Adult participation coaching}

After round one, 88 statements were extracted and were subsequently presented as items in round two relating to the characteristics of expertise $(n=44)$ and development requirements $(n=44)$. Forty-one statements of characteristics of expertise and 34 of the development requirements obtained a mean rating of $\geq 3.75$ and were therefore presented in the round three. Sixteen of the characteristics of expertise and seven development requirements gained agreement $\geq 51 \%$ to be ranked in round four (see Table 4 and 5 respectively).

Characteristics of expertise emerging with a high rating were connected to managing challenging situations, raising confidence and adapting the environment. The importance of the personal 
Table 4. Prime defining characteristics of expertise for the Adult participation domain

\begin{tabular}{|c|c|c|c|c|}
\hline $\begin{array}{l}\text { Item } \\
\text { no. }\end{array}$ & Characteristic of expertise $(n=16)$ & Mean & $\mathrm{SD}$ & Rank \\
\hline \multicolumn{5}{|c|}{ Wider sport knowledge } \\
\hline 1 & $\begin{array}{l}\text { Can break down barriers to } \\
\text { participation }\end{array}$ & 3.67 & 0.48 & 10 \\
\hline \multicolumn{5}{|c|}{ Athlete-centred coaching } \\
\hline 2 & Raises confidence & 3.89 & 0.31 & 2 \\
\hline \multirow[t]{2}{*}{3} & Can maintain interest & 3.78 & 0.42 & 4 \\
\hline & Management and organisation & & & \\
\hline 4 & Managing challenging situations & 4.00 & 0.00 & 1 \\
\hline 5 & Can adapt the environment & 3.89 & 0.31 & 2 \\
\hline 6 & Gives clear instructions & 3.78 & 0.42 & 4 \\
\hline \multirow[t]{2}{*}{7} & Plans sessions and is creative & 3.67 & 0.48 & 10 \\
\hline & Coach-athlete relationship & & & \\
\hline \multirow[t]{2}{*}{8} & Builds positive relationships & 3.67 & 0.48 & 10 \\
\hline & Growth mind set & & & \\
\hline 9 & Is flexible & 3.78 & 0.42 & 4 \\
\hline \multirow[t]{2}{*}{10} & Thinks outside of the box & 3.78 & 0.42 & 4 \\
\hline & Character & & & \\
\hline 11 & Is motivational & 3.78 & 0.42 & 4 \\
\hline 12 & Transmits energy to the participants & 3.78 & 0.42 & 4 \\
\hline 13 & Shows a passion for netball & 3.67 & 0.48 & 10 \\
\hline 14 & Is polite and welcoming & 3.67 & 0.48 & 10 \\
\hline 15 & Is approachable & 3.67 & 0.67 & 15 \\
\hline 16 & Is friendly & 3.67 & 0.67 & 15 \\
\hline
\end{tabular}

characteristics of the coach was revealed with six items listed under Character. Table 5 reveals the unmediated category emerged as an important form of learning and the highest ranked item was related to the importance of coaching experience and adapting in-action. The ability to engage and work with individuals of different backgrounds, ethnicities and needs was deemed an important requirement for the development of expertise. An individual's approach to learning was also deemed important with the open-mindedness to engage and the approach to learning being highlighted.

\section{Sustaining participation coaching}

Seventy-five items were extracted from round one and were subsequently used in round two (characteristics of
Table 5. Prime development requirements for the Adult participation domain

\begin{tabular}{|c|c|c|c|c|c|}
\hline $\begin{array}{l}\text { Item } \\
\text { no. }\end{array}$ & $\begin{array}{l}\text { Form of } \\
\text { Learning }\end{array}$ & Development requirement $(\mathrm{n}=7)$ & Mean & SD & Rank \\
\hline 1 & Unmediated & When coaching and adapting a plan & 4.00 & 0.00 & 1 \\
\hline 2 & & $\begin{array}{l}\text { Working with different ethnicities, } \\
\text { age and socio-economic groups }\end{array}$ & 3.78 & 0.42 & 2 \\
\hline 3 & & By gaining experience & 3.56 & 0.50 & 6 \\
\hline 4 & & Coaching regularly & 3.56 & 0.50 & 6 \\
\hline 5 & Internal & $\begin{array}{l}\text { Being open-minded and prepared to } \\
\text { learn }\end{array}$ & 3.78 & 0.42 & 2 \\
\hline 6 & & $\begin{array}{l}\text { Knowing aspects of a coaching } \\
\text { session will not always work }\end{array}$ & 3.67 & 0.47 & 4 \\
\hline 7 & & $\begin{array}{l}\text { Possessing good skills and an } \\
\text { interest }\end{array}$ & 3.67 & 0.47 & 4 \\
\hline
\end{tabular}

expertise, $n=48$; development requirements, $n=28$ ). All 48 characteristics of expertise items achieved a mean score of $\geq 3.75$ or higher mean score. Following an open-text box entry and subsequent discussion with one participant, there was a strong case for adding another item based on their particular expertise in managing stakeholders. The remaining participants subsequently agreed and therefore a total of 49 items were presented for round three. Twenty-three development requirement items were retained for round three. In round three, 34 characteristics of expertise statements and 10 development requirements achieved $\geq 51 \%$ agreement and so were retained to be ranked in round four (see Table 6 and 7 respectively).

The importance of coach communication and a 'user-friendly' style were key characteristics of expertise. Other highly ranked items included organisation and the ability to encourage and motivate. The approach to one's coaching and to learning were emphasised as important facets of the expert sustaining performance coach. Being open to learning, adaptable and creative were key characteristics cited. The participants identified the importance of unmediated learning and engaging in coaching a range of participants as important development requirements. Coaches in this category cited mediated forms of learning such as workshops and qualifications as critical to the 
Table 6. Prime defining characteristics of expertise for the Sustaining participation domain

\begin{tabular}{|c|c|c|c|c|}
\hline $\begin{array}{c}\text { Item } \\
\text { no. }\end{array}$ & Characteristic of expertise $(n=34)$ & Mean & $\mathrm{SD}$ & Rank \\
\hline & Wider sport knowledge & & & \\
\hline 1 & Participant motives and needs & 3.86 & 0.12 & 10 \\
\hline 2 & Child protection & 3.29 & 0.10 & 33 \\
\hline \multirow[t]{2}{*}{3} & First Aid & 3.29 & 0.10 & 33 \\
\hline & Practice and environmental design & & & \\
\hline 4 & Up-to-date knowledge & 3.86 & 0.11 & 8 \\
\hline 5 & Break-down skills & 3.86 & 0.18 & 20 \\
\hline 6 & Rules of the game & 3.71 & 0.11 & 23 \\
\hline 7 & Game knowledge & 3.71 & 0.14 & 27 \\
\hline \multirow[t]{2}{*}{8} & Training methods & 3.71 & 0.14 & 27 \\
\hline & Athlete-centred coaching & & & \\
\hline 9 & Equitable & 3.86 & 0.16 & 19 \\
\hline 10 & Adopt the holistic approach & 3.86 & 0.35 & 21 \\
\hline 11 & Be a facilitator and question others & 3.57 & 0.20 & 32 \\
\hline \multirow[t]{2}{*}{12} & Promote fitness and a healthy lifestyle & 3.57 & 0.11 & 30 \\
\hline & Management and organisation & & & \\
\hline 13 & Communicate in a user-friendly style & 4.00 & 0.00 & 1 \\
\hline 14 & Organisation & 4.00 & 0.00 & 1 \\
\hline 15 & Promote two-way communication & 4.00 & 0.00 & 1 \\
\hline 16 & Provide a safe environment & 3.86 & 0.11 & 8 \\
\hline 17 & Generate and give feedback & 3.86 & 0.12 & 10 \\
\hline 18 & Offer progressive sessions & 3.86 & 0.13 & 13 \\
\hline \multirow[t]{2}{*}{19} & Plan, deliver and review & 3.71 & 0.13 & 26 \\
\hline & Coach-athlete relationship & & & \\
\hline \multirow[t]{2}{*}{20} & Personable and empathetic & 3.86 & 0.14 & 15 \\
\hline & Growth mind set & & & \\
\hline 21 & Be open to learning & 4.00 & 0.00 & 1 \\
\hline 22 & Adaptable & 4.00 & 0.00 & 1 \\
\hline 23 & Creative in one's approach & 4.00 & 0.00 & 1 \\
\hline \multirow[t]{2}{*}{24} & Open minded & 3.86 & 0.35 & 21 \\
\hline & Character & & & \\
\hline 25 & Encouraging and motivating & 4.00 & 0.00 & 1 \\
\hline 26 & Reliable & 3.86 & 0.12 & 10 \\
\hline 27 & Patience & 3.86 & 0.13 & 13 \\
\hline 28 & A good listener & 3.86 & 0.14 & 15 \\
\hline 29 & Approachable & 3.86 & 0.15 & 17 \\
\hline 30 & Enthusiastic & 3.86 & 0.15 & 17 \\
\hline 31 & Promote enjoyment & 3.71 & 0.11 & 23 \\
\hline 32 & Leadership & 3.71 & 0.12 & 25 \\
\hline 33 & Diplomatic and fair & 3.71 & 0.45 & 29 \\
\hline 34 & Be an effective decision-maker & 3.57 & 0.12 & 31 \\
\hline
\end{tabular}

Table 7. Prime development requirements for the Sustaining participation domain

\begin{tabular}{|c|c|c|c|c|c|}
\hline $\begin{array}{c}\text { Item } \\
\text { no. }\end{array}$ & $\begin{array}{l}\text { Form of } \\
\text { learning }\end{array}$ & $\begin{array}{l}\text { Development requirement } \\
\qquad(\mathrm{n}=10)\end{array}$ & Mean & SD & Rank \\
\hline 1 & Mediated & Qualification courses & 3.71 & 0.49 & 2 \\
\hline 2 & & Coaching workshops & 3.71 & 0.50 & 3 \\
\hline 3 & & Technical specific workshops & 3.57 & 0.53 & 5 \\
\hline 4 & & Mentoring & 3.29 & 0.76 & 9 \\
\hline 5 & & $\begin{array}{l}\text { Coaching course with follow } \\
\text { up mentoring }\end{array}$ & 3.29 & 0.76 & 10 \\
\hline 6 & Unmediated & $\begin{array}{l}\text { Coaching a range of } \\
\text { participants in a club }\end{array}$ & 3.86 & 0.38 & 1 \\
\hline 7 & & Self-reflection and evaluation & 3.71 & 0.50 & 3 \\
\hline 8 & & $\begin{array}{c}\text { Coaching in a range of } \\
\text { environments }\end{array}$ & 3.57 & 0.77 & 6 \\
\hline 9 & & On the job learning 'in situ' & 3.43 & 0.79 & 8 \\
\hline 10 & $\begin{array}{l}\text { Internal } \\
\text { Learning }\end{array}$ & $\begin{array}{l}\text { Knowledge of oneself and } \\
\text { gaps in knowledge }\end{array}$ & 3.43 & 0.54 & 7 \\
\hline
\end{tabular}

development of expertise. An individual's ability to reflect and evaluate one's coaching was noted as important for development.

\section{Performance development coaching}

Following round one, 76 statements were extracted (characteristics of expertise, $n=48$; development requirements, $n=28$ ). Forty-seven characteristics of expertise items and 22 development requirement items were retained because their mean score was $\geq 3.75$ in round two. One participant highlighted the need to consider coaching in other cultures; consensus was achieved by an agreement that the item coaching in new environments covered this issue. Following round three, 29 characteristics of expertise items and 10 development requirement items achieved a rating of $\geq 51 \%$ and so were retained and ranked within round four. The strength of agreement for the characteristics of expertise and ranking for each item are presented in Table 8 .

The three highest ranked items resided within the subject and pedagogical knowledge domain and conveyed the importance of the coach possessing knowledge of game principles, a capacity to engage in 
Table 8. Prime defining characteristics of expertise for the Performance development domain

\begin{tabular}{|c|c|c|c|c|}
\hline $\begin{array}{l}\text { Item } \\
\text { no. }\end{array}$ & Characteristic of expertise $(n=29)$ & Mean & SD & Rank \\
\hline \multicolumn{5}{|c|}{ Wider sport knowledge } \\
\hline 1 & Player pathway & 3.73 & 0.45 & 11 \\
\hline 2 & Recognise talent and potential & 3.73 & 0.45 & 11 \\
\hline 3 & Characteristics of an elite athlete & 3.64 & 0.48 & 14 \\
\hline \multicolumn{5}{|c|}{ Practice and environmental design } \\
\hline 4 & Game principles & 4.0 & 0.00 & 1 \\
\hline 5 & Technical and tactical & 3.91 & 0.29 & 4 \\
\hline 6 & Read the game & 3.73 & 0.64 & 13 \\
\hline 7 & Analyse performance in netball & 3.64 & 0.48 & 14 \\
\hline \multicolumn{5}{|c|}{ Athlete-centred coaching } \\
\hline 8 & Player-centred approaches & 3.91 & 0.29 & 4 \\
\hline 9 & Empowering others & 3.82 & 0.39 & 8 \\
\hline 10 & Problem-solving & 3.64 & 0.48 & 14 \\
\hline 11 & Shape the learning environment for all & 3.55 & 0.50 & 23 \\
\hline \multicolumn{5}{|c|}{ Management and organisation } \\
\hline 12 & Observation & 4.00 & 0.00 & 1 \\
\hline 13 & Communication & 4.00 & 0.00 & 1 \\
\hline 14 & Self-reflection & 4.00 & 0.00 & 1 \\
\hline 15 & Plan and review & 3.64 & 0.48 & 14 \\
\hline 16 & Employ a range of coaching styles & 3.64 & 0.64 & 23 \\
\hline \multicolumn{5}{|c|}{ Coach-athlete relationship } \\
\hline 17 & Approachable & 3.64 & 0.48 & 14 \\
\hline 18 & Inter-personal skills & 3.55 & 0.50 & 22 \\
\hline 19 & Empathetic & 3.45 & 0.50 & 28 \\
\hline \multicolumn{5}{|c|}{ Growth mind set } \\
\hline 20 & Receptive to change & 3.64 & 0.48 & 14 \\
\hline 21 & Flexibility & 3.64 & 0.48 & 14 \\
\hline 22 & Admit to making mistakes & 3.64 & 0.64 & 23 \\
\hline \multicolumn{5}{|c|}{ Character } \\
\hline 23 & Motivate and be Inspirational & 3.91 & 0.29 & 4 \\
\hline 24 & Show passion and enthusiasm & 3.91 & 0.29 & 4 \\
\hline 25 & Honesty & 3.82 & 0.39 & 8 \\
\hline 26 & Determination & 3.64 & 0.48 & 14 \\
\hline 27 & Creative and thoughtful & 3.64 & 0.48 & 14 \\
\hline 28 & Respect & 3.64 & 0.64 & 23 \\
\hline 29 & Confidence & 3.55 & 0.50 & 27 \\
\hline
\end{tabular}

Table 9. Prime development requirements for the Performance development domain

\begin{tabular}{|c|c|c|c|c|c|}
\hline $\begin{array}{l}\text { Item } \\
\text { no. }\end{array}$ & $\begin{array}{l}\text { Form of } \\
\text { learning }\end{array}$ & Development requirement $(\mathrm{n}=10)$ & Mean & $\mathrm{SD}$ & Rank \\
\hline 1 & Unmediated & Actual coaching & 3.82 & 0.39 & 1 \\
\hline 2 & & $\begin{array}{l}\text { Asking questions to other } \\
\text { experts }\end{array}$ & 3.82 & 0.39 & 1 \\
\hline 3 & & Self-reflection & 3.64 & 0.48 & 6 \\
\hline 4 & & Conversations with elite coaches & 3.64 & 0.48 & 6 \\
\hline 5 & & $\begin{array}{l}\text { Observe national and regional } \\
\text { coaching }\end{array}$ & 3.64 & 0.48 & 6 \\
\hline 6 & & $\begin{array}{l}\text { Talking to and feedback from } \\
\text { athletes }\end{array}$ & 3.55 & 0.50 & 9 \\
\hline 7 & & Talking to others & 3.45 & 0.50 & 10 \\
\hline 8 & $\begin{array}{l}\text { Internal } \\
\text { Learning }\end{array}$ & Internal desire to develop & 3.82 & 0.39 & 1 \\
\hline 9 & & Engage in a range of learning & 3.82 & 0.39 & 1 \\
\hline 10 & & $\begin{array}{l}\text { Expose oneself to new coaching } \\
\text { contexts }\end{array}$ & 3.73 & 0.45 & 5 \\
\hline
\end{tabular}

accurate observation of performance and communicate effectively with athletes. The ranking also highlighted the importance of technical and tactical knowledge along with a player-centred approach to delivery and athlete management. Personal qualities of the coach were also identified and featured the importance of the ability to motivate, being inspirational, passionate and enthusiastic was noted for a coach within the Performance development context. The strength of agreement for the development requirements and ranking for each item are presented in Table 9.

The unmediated and internal forms of learning were identified as being important for the development of expertise. Seven items were contained within the unmediated category with one's actual coaching and asking questions to other experts receiving the highest ranked scores. An individual's approach to learning and desire to want to develop as a coach was noted along with the need to engage in a range of learning opportunities to develop expertise. 


\section{High-performance (elite) coaching}

Following round one, 98 items were extracted and presented for round two to represent the characteristics of expertise $(n=57)$ and development requirements $(n$ 41). Upon completion of round two, 54 items achieved a mean score of $\geq 3.75$ for the characteristics of expertise and 38 items represented development requirements. In round three, 31 items achieved $\geq 51 \%$ agreement as a characteristic of expertise and 11 items as development requirements for the high-performance context. In round four an agreement was obtained; Table 10 reveals the mean scores and ranking of the characteristics for expertise items.

Four expert characteristics received the maximum highest agreement for this domain ( $\mathrm{M}=4.00)$, including the need for a coach to possess a working knowledge of the elite performance environment. In relation to management and organisational characteristics, communication and the ability to promote quality performance when coaching were identified as crucial. Additionally, an expert within this domain was also identified as an individual able to build and manage relationships with integrity. A number of other items scored very highly, if not perfectly, including effective leadership, the ability to manage a team and promoting discipline and a work ethic. An overall commitment to learning and recognition of one's own strengths in this process were also cited as key for the expert high-performance coach. The capacity of this coach to manage one's own emotions and those of others was reiterated with emotional intelligence being raised as a necessity.

In terms of development requirements, the unmediated and internal forms of learning were noted by the participants (see Table 11). The highest ranked item was closely connected to the individual coaches' psyche and the ability to adopt a positive attitude to learning. A commitment to learning, showing a positive work ethic and intrinsic motivation were deemed essential requisites. The impact of social interaction in
Table 10. Prime defining characteristics of expertise for the High-performance domain

\begin{tabular}{|c|c|c|c|c|}
\hline $\begin{array}{c}\text { Item } \\
\text { no. }\end{array}$ & Characteristic of expertise $(n=31)$ & Mean & $\mathrm{SD}$ & Rank \\
\hline \multicolumn{5}{|c|}{ Practice and environmental design } \\
\hline 1 & Knowledge of the elite environment & 4.00 & 0.00 & 1 \\
\hline 2 & Knowledge of rules & 3.88 & 0.33 & 5 \\
\hline 3 & Components of performance & 3.88 & 0.33 & 5 \\
\hline 4 & Coordinate long term programmes & 3.75 & 0.66 & 20 \\
\hline 5 & Know the tactical nuances & 3.71 & 0.45 & 23 \\
\hline \multicolumn{5}{|c|}{ Athlete-centred coaching } \\
\hline 6 & Adopt the holistic approach & 3.88 & 0.33 & 5 \\
\hline \multicolumn{5}{|c|}{ Management and organisation } \\
\hline 7 & Emphasise the 'quality' when coaching & 4.00 & 0.00 & 1 \\
\hline 8 & Communication & 4.00 & 0.00 & 1 \\
\hline 9 & Develop and manage a team & 3.88 & 0.33 & 5 \\
\hline 10 & Promote discipline and a work ethic & 3.88 & 0.33 & 5 \\
\hline 11 & Effective leadership & 3.88 & 0.33 & 5 \\
\hline 12 & Organisational skills & 3.75 & 0.43 & 15 \\
\hline 13 & Observe, analyse and evaluate & 3.75 & 0.43 & 15 \\
\hline 14 & Problem-solving to meet athlete needs & 3.63 & 0.48 & 24 \\
\hline 15 & Embrace other experts and support staff & 3.50 & 0.50 & 30 \\
\hline \multicolumn{5}{|c|}{ Coach-athlete relationship } \\
\hline 16 & $\begin{array}{l}\text { Manage people and build relationships with } \\
\text { integrity }\end{array}$ & 4.00 & 0.00 & 1 \\
\hline 17 & Show commitment & 3.88 & 0.33 & 5 \\
\hline 18 & Show trust & 3.63 & 0.70 & 29 \\
\hline \multicolumn{5}{|c|}{ Growth mind set } \\
\hline 19 & Self-responsibility & 3.75 & 0.43 & 15 \\
\hline 20 & Self-awareness & 3.75 & 0.43 & 15 \\
\hline 21 & Value continual learning & 3.75 & 0.43 & 15 \\
\hline 22 & Emotional intelligence & 3.63 & 0.48 & 24 \\
\hline 23 & Flexible and open-minded & 3.63 & 0.48 & 24 \\
\hline 24 & Listen to other experts & 3.50 & 0.50 & 30 \\
\hline 25 & Move out of one's comfort zone & 3.38 & 0.70 & 33 \\
\hline \multicolumn{5}{|c|}{ Character } \\
\hline 26 & Be transparent and consistent & 3.88 & 0.33 & 5 \\
\hline 27 & Make decisions under pressure & 3.88 & 0.33 & 5 \\
\hline 28 & Have passion and drive to excel & 3.75 & 0.66 & 20 \\
\hline 29 & Action one's own philosophy and vision & 3.75 & 0.87 & 22 \\
\hline 30 & Passionate and motivational & 3.63 & 0.48 & 24 \\
\hline 31 & Resilience & 3.63 & 0.48 & 24 \\
\hline
\end{tabular}


Table 11. Prime defining development requirements for the High-performance domain

\begin{tabular}{|c|c|c|c|c|c|}
\hline $\begin{array}{l}\text { Item } \\
\text { no. }\end{array}$ & $\begin{array}{l}\text { Form of } \\
\text { learning }\end{array}$ & Development requirement $(\mathrm{n}=11)$ & Mean & $\mathrm{SD}$ & Rank \\
\hline 1 & Unmediated & Self-reflection & 3.75 & 0.43 & 2 \\
\hline 2 & & $\begin{array}{l}\text { Conversations with coaches across } \\
\text { sports }\end{array}$ & 3.50 & 0.50 & 5 \\
\hline 3 & & Real-life opportunities in competition & 3.50 & 0.70 & 7 \\
\hline 4 & & Be an assistant coach & 3.00 & 0.70 & 7 \\
\hline 5 & & $\begin{array}{l}\text { Visit other countries and game in } \\
\text { action }\end{array}$ & 3.38 & 0.70 & 7 \\
\hline 6 & & Transfer key skills from other areas & 3.50 & 0.70 & 7 \\
\hline 7 & $\begin{array}{l}\text { Internal } \\
\text { Learning }\end{array}$ & Positive attitude towards learning & 4.00 & 0.00 & 1 \\
\hline 8 & & Possessing a strong work ethic & 3.75 & 0.43 & 2 \\
\hline 9 & & $\begin{array}{l}\text { Engage in a range of learning } \\
\text { experiences }\end{array}$ & 3.63 & 0.48 & 4 \\
\hline 10 & & Commit to develop your own style & 3.63 & 0.48 & 4 \\
\hline 11 & & Coach must have intrinsic motives & 3.25 & 0.66 & 6 \\
\hline
\end{tabular}

the form of discussions and conversations with other coaches was highlighted in the findings. Engaging in a range of learning experiences and coaching opportunities such as being an assistant coach and visiting other countries to observe the game appeared significant in the development of expertise.

This study has identified similar features of expertise within the coaching domains; however, there are differences in the highly ranked items representing the characteristics and development requirements for expertise. All cited items representing expertise fall within the seven themes of wider sport knowledge, practice and environmental design, athlete-centred coaching, management and organisation, growth mind set and character. The dominance of the unmediated and internal forms of learning was apparent across four coaching domains, with only the sustaining participation coach citing the mediated form of learning as important. A common requirement for the development of expertise across all domains is the coach's ability to manage change, learn from mistakes and engage in reflective practice. Differences have also been noted between the five coaching domains reflecting the bespoke outcomes, motives and needs of the participants, which will be discussed more extensively in the next section.

\section{Discussion}

The aim of this study was to explore and develop a consensus of opinion from expert netball coaches drawn from the range of coaching domains apparent within UK netball by exploring the prime defining characteristics of, and the prime development requirements for, coaching expertise. This study therefore investigated the opinions of coaching experts within the five identified coaching domains in netball, namely: Children's, Adult participation, Sustaining participation, Performance development and High-performance (elite). The results show common trends and distinct characteristics of expertise for the five coaching domains in netball. Expertise manifests itself in seven common themes namely; wider sport knowledge, practice and environmental design, athlete-centred coaching, management and organisation of the coaching process, coach-athlete relationships, growth mind set and character. This discussion will examine the prime defining characteristics of expertise and development requirements for each of the five netball coaching contexts. Following the first domain (Children's coaching), the following sections focus on the areas which are different from those already discussed. Throughout the discussion, the numbers of specific items are presented in square brackets (e.g. [11]).

\section{Children's coaching}

Six of the seven most highly ranked items featured in Table 2 and emanating from the children's domain were drawn from the 'Athlete-centred coaching' and 'Management and organisation' categories and are wholly commensurate with the considerable volume of research promoting PYD (Côté \& Gilbert, 2009; 
Vierimaa, Erickson, Côté, \& Gilbert, 2012). The focus on effort, praise and positive reinforcement aligns with the creation of a positive motivational climate and, specifically, a mastery-focused environment (Allen \& Hodge, 2006) as well as the importance of delivering activities which are inherently enjoyable (Bengoechea, Strean, \& Williams, 2004; Côté, Lidor, \& Hackfort, 2009). However, our findings in this domain reveal no mention of autonomy or empowerment - terms which are aligned to positive motivational climates and which have been commonly advocated (Allen \& Hodge, 2006; R. E. Smith, Smoll, \& Cumming, 2009). Empowerment does not feature as a consensus item until the performance-related domains and so it appears our expert coaches did not agree that this was a necessary component in either Children's or participation-related domains. This finding suggests that the expert coaches in this investigation believed that empowering athletes is not a one-size-fits-all approach and that autonomy should be carefully deployed depending on the context and domain - as advocated by Nelson, Cushion, Potrac, and Groom (2014) and Vinson and Bell (2020). Nevertheless, the characteristics of expertise identified within this domain do feature a number of items which encourage a degree of athlete input (e.g. 'promotes self-discovery' [11], 'promotes open-ended questioning' [18]) although they rank at the lower end of the list (19 and below). Self-discovery, alongside the 'uses game-like situations' [1] and 'can condition activities' [3] items suggest that the expert coaches advocated a games-based, context-rich, approach to children's coaching (see Harvey \& Jarrett, 2014).

The middle-ranked characteristics of expertise within the Children's domain suggest the coaches agreed on the importance of the psychological safety of the athletes (see Strachan, Côté, \& Deakin, 2011). Our findings suggest the expert children's coach should plan appropriate progressions and coach fundamental skills in an environment where risk is minimised, and physical safety has been assured. Perhaps surprisingly, our participants did not agree on the importance of managing parental involvement $-\mathrm{a}$ theme which is emerging in contemporary research (Harwood, Knight, Thrower, \& Berrow, 2019). Nevertheless, a successful coach-athlete relationship has been identified by our participants as one which fosters commitment, sets appropriate boundaries and ensures the coach is approachable; Côté, Salmela, and Russell (1995) similarly outlined the importance of setting appropriate professional boundaries for success in the coaching role. Coach character has received a great deal of attention in this study when compared to previous findings which have tended to emphasise pedagogical and sport-specific knowledge (e.g. Abraham et al., 2006). For the children's coach, the social (fairness [28], patience [32], and approachability [24]), emotional (inspirational [31]) and psychological factors (will commit time and effort [26]) are reported as critical attributes of the coach. In support of these findings, Gould and Carson (2004) outlined the need for the coach to promote the development of life skills through emphasising hard work, being a positive role model and showing good sportsmanship.

In terms of the development requirements, five forms of learning were identified by the participants and were categorised as unmediated and internal (see Table 3). Open-mindedness, knowledge of oneself and coping with change were identified as important thus confirming the importance of self-regulation and reflection (Moon, 2004; Zimmerman, 2005). The identification of 'Open discussion with others' [2] reflects recent research which has emphasized coaches' preference for learning environments which are informal and feature a high degree of social interaction (Stoszkowski \& Collins, 2016). The importance of the individuals' mind set and approach to learning is highly weighted when compared to previous literature (Erickson et al., 2007). Overall within the Children's domain, Côté et al.'s (2010) foundation of the 4Cs of confidence, connection, connection and character is supported by these findings and, in particular, the domains of inter-personal and intrapersonal forms of knowledge. 


\section{Adult participation coaching}

The nine highest ranking items within the Adult participation coaching domain surrounded the episodic delivery of sessions and were spread across the 'Athlete-centred coaching', 'Management and organisation', 'Growth mind set' and 'Character' categories (see Table 4). The consensus of our participants reflects Lyle's (Lyle, 2002) definition of participation coaching - i.e. a loose membership of individuals, transient participation and a predominant focus on the positive affective outcomes such as perceptions of competence and enjoyment. Therefore, for adult participation coaches, the expertise required appears to concern the initial capturing of the attendees' enthusiasm and then sustaining this interest over the long term (Allen, Bell, Lynn, Taylor, \& Lavallee, 2012). Within a participation context, an individual's motives for engagement are best understood as a combination of psychosocial and cultural factors (Duchesne, Bloom, \& Sabiston, 2011; Gilbert \& Trudel, 2004). Our findings reflect these perspectives in that those items ranked one to four - e.g. recognition of the need to 'manage challenging situations' [4], 'can adapt the environment' [5] and 'transmits energy to participants' [12], capture the complexity of understanding and catering for a wide range of differing motives and expectations. These characteristics of expertise reflect the "broader" definition of coaching proposed within Coaching in an Active Nation: The coaching plan for England 2017-2021 (Sport England, 2016b, p. 4). Furthermore, the ability to be 'flexible' [9] and to 'think outside the box' [10] also reflect contemporary thinking when considering the multifaceted role of the coach (Vinson et al., 2016), especially in light of the professionalization debate (Taylor \& Garratt, 2010b).

The ability of a coach to enhance participants' confidence was the second most highly ranked characteristic of expertise. Cronin and Armour (2019) outlined the importance of the coach in building confidence through adopting a caring approach. A caring approach is commensurate with our findings where the majority of mid-low ranked characteristics of expertise within this domain largely surrounded prosocial character traits such being polite, approachable and friendly. The coach role in this context is not focused upon technical development or winning. Proficiency in this domain is more closely related to the conceptual model offered by Jowett (2017) where expertise was associated with the construction of a quality coach-athlete relationship.

The importance of unmediated and internal forms of learning were again established within this domain (see Table 5). Coaching experience accompanied with the ability to adapt in-situ was the most highly ranked item and reflects a considerable volume of research which has highlighted experiential learning to be coaches' most useful mode (e.g. Blackett, Evans, \& Piggott, 2017; Stoszkowski \& Collins, 2016). The emphasis on experiential learning reflects the process of reflection in action as advocated by Schön (1987) and is commonly cited across the reflective learning literature (e.g. Moon, 2004). Interestingly, the coaches in this group did not report on the importance of reflection on or through action, perhaps further indicating the more episodic and immediate nature of coaching expertise in the Adult participation domain. Being open-minded, knowing aspects of a session may not be successful and showing an interest in the participants were identified as development requirements. These findings support the view of Schempp et al. (2006) who stated that the expert coach should assume a high level of responsibility for any learning problems encountered and will analyse practice, adapt and make changes in a session and seek out new resources. Overall, the complexity of facilitating engaging sessions for participants holding a wide range of motives, expectations and requirements was evident throughout both the characteristics of expertise and development requirements in the adult participation domain. The immediate and episodic focus was also evident and characterizes the nature of the role of the expert coach in this domain. 


\section{Sustaining participation coaching}

Whilst coaches within the two previous domains are solely focused on participation with a predominantly recreational focus, sustaining participation coaches represent the first stage were a performance agenda is apparent - albeit a secondary concern to encouraging a lifelong commitment to the sport. Engaging with participants who possess multiple objectives is a feature of this domain with some individuals likely to enter a performance pathway and others taking part recreationally. Young participants cite achievement, success, teamwork, improving fitness, affiliation, friendship and fun as motives (Gilbert \& Trudel, 2004). Nevertheless, as the participation agenda remains the dominant focus for sustaining participation coaches, it is unsurprising that the most highly ranked characteristics of expertise were very similar to those reported within the adult participation domain; items relating to communication, organisation, being open to learning, being adaptable and being encouraging and motivation received complete agreement from all participants (see Table 6).

A principal point of difference from the two previous domains when considering the characteristics of expertise lies in the lowlier ranked items (20-27) which centre around coaches' technical knowledge in terms of their understanding of the game and training methods. Despite being lowly ranked, the individual items scores remain very high (Mean range $=3.86-3.71 \pm 0.18-0.14$ ) demonstrating that the vast majority of respondents consider these items to be very relevant for the sustaining participation coach - commensurate with a number of previous investigations which have reported organisation (Nash \& Collins, 2006), planning (Abraham et al., 2006) and technical/tactical knowledge (Nash \& Sproule, 2011) to be crucial for expert coaches. Another notable difference was the reporting of effecting decision-making as a characteristic of expertise. Klein (1997) believed the expert coach could focus on the most relevant information which would ultimately ensure effective feedback is provided to the participant; concomitantly, consensus was reached in this investigation that experts in this domain must be able to 'generate and give feedback' [17].

The development requirements of the Sustaining participation coach were quite different from the two previous domains (see Table 7). The importance of mediated learning and certificated formal coaching qualifications were notably highlighted. Despite the widespread criticism of formal coach education courses (see, for example, Mallett et al., 2009; Piggott, 2012), our participants reached consensus on four items comprising qualifications and workshops, suggesting support for such provision within the sport of netball might be stronger than in other contexts. Nevertheless, our findings were aligned with the wide range of previous research which has advocated mentoring as a crucial development requirement. Knowles, Borrie, and Telfer (2005) believed a reflective approach should be incorporated into coach education programmes in order to ensure greater benefits for coach development. Furthermore, collaborative reflection is encouraged through mentoring; Cushion, Armour, and Jones (2006) confirmed the benefits of this process for developing professional practice and knowledge. These perspectives capture the range of mediated, unmediated and internal learning requirements reported by our participants, advocating such approaches as important for the Sustaining participation coach.

\section{Performance Development Coaching}

A coach within this domain has a multifaceted role in supporting the athlete to achieve performance outcomes and also to ensure support systems are in place to enhance the all-round development of the individual (England Netball, 2018). Unsurprisingly then, understanding 'characteristics of an elite athlete' [3] and knowledge of the 'player pathway' [1] were identified as characteristics of expertise (see Table 8). A coach must understand the progression points within 
the pathway and recognise talented and performers of high potential (Collins, MacNamara, \& Cruickshank, 2018). Similarly, our findings also reflect research which has advocated an awareness of adolescent athlete development and the related interaction with performance demands (Côté \& Gilbert, 2009).

A distinct difference between the Performance development and Sustaining participation domain is highlighted by the relative differences in rank order assigned to items related to sport-specific, professional, knowledge. Consensus was reached by our participants in relation to a number of items under the practice and environmental design category including 'game principles' [4], 'technical and tactical' [5], 'read the game' [6] and 'analyse performance in netball' [7]. The importance of the ability to evaluate player potential, to analyse in relation to talent identification, processing tactical strategies and evaluating technical performance affirms previous research (Becker, 2009). The consensus items within the Performance development domain are the first within this investigation to highlight the importance of empowerment. Whilst praising the altruistic intent of those coaches who attempted to empower their athletes, Denison, Mills, and Konoval (2017) recently questioned the authenticity of such approaches suggesting that, given the unavoidable hierarchical power held by coaches, choices provided to athletes were little more than an illusion of autonomy. Our findings indicate a consensus in conflict with Denison et al.'s (2017) perspective and are more in-line with other research which has continued to advocate the importance of athlete empowerment (e.g. Allen \& Hodge, 2006; Occhino, Mallett, Rynne, \& Carlisle, 2014). Vinson and Bell (2020) recently suggested that a coach can deploy an empowering approach without having to consider it a 'one-size-fits-all approach'. More items are reported within the Performance development domain in relation to the coach-athlete relationship than were apparent within the previous areas suggesting an enhanced importance of these bonds as athlete progress through the performance pathway and which supports
Jowett's (2017) contention. These findings are underlined by the large number of items throughout the ranking which would underpin high quality coach-athlete relationships (e.g. player-centred approaches, communication, approachable, flexibility, honest, creative and thoughtful).

The development requirements of the Performance development coach represent a much broader range of influences than reported in the previous domains (see Table 9). The consensus reached concerning the importance of experiential learning, talking to other experts, observing other settings and seeking feedback from others strongly aligns with contemporary thinking concerning coach learning (Bertram, Culver, \& Gilbert, 2017). Specifically, Trudel and Gilbert (2013) posited that coaches should be aiming to move from dependence through independence and towards interdependence as they develop expertise. Additionally, the broad range of stakeholders and settings identified by our participants align strongly with the development of knowledgeability across individual coaches' LoP (Wenger-Trayner \& Wenger-Trayner, 2015). Developing one's knowledgeability requires crossing numerous 'boundaries' of practice - sociocultural differences which lead to some kind of discontinuity in action or identity. All such boundary crossings hold the potential for coach learning (Akkerman \& Bakker, 2011) and our participants have highlighted the importance of taking such steps in order to develop coaching expertise.

\section{High-Performance (Elite) Coaching}

High-performance and elite coaching has featured more prominently in the expertise literature than any other domain. The results of our investigation reveal a broad range of items from across six of the seven thematic categories and which are broadly supportive of a wide range of research in this field (see Table 10). Very few items were generated which have not been apparent in any of the previous four domains although 
the emphasis, as with the performance development coaches, remains on a high level of professional knowledge and quality coach-athlete relationships. One item which is distinct from the other four domains features the emphasis on being able to 'make decisions under pressure' [27]. The frequent goal scoring, short intervals and close score lines which are so regularly apparent in high-performance netball ensure the coach is frequently called-on to make highly pressurized decisions in short time-frames. Recent research has questioned whether the foundation for such decision-making is based more heavily on pre-competition planning where a wide range of possible permutations are considered (Abraham \& Collins, 2011) or on more naturalistic, at-action, intuitive factors (Harvey, Lyle, \& Muir, 2015). The nature of the Delphi approach does not enable us to explore this matter further here, but future investigations should continue to explore the nature of expert coach decision-making in high-performance netball.

Our findings position the coach as leader more prominently than in the previous domains. 'Management and organisation' items comprising 'effective leadership' [11], 'develop and manage a team' [9], 'embrace other experts and support staff' [15] confirm the consensus of our participants that see the expert coach in this domain as a multidisciplinary professional (Hodge, Henry, \& Smith, 2014). When considered alongside other items such as 'action one's own philosophy and vision' [29], 'emotional intelligence' [22], 'passionate and motivational' [30], it is evident that our panel's understanding of expert coach leadership is aligned with recent research from Turnnidge and Côté (2018) which has outlined Transformational Leadership as an appropriate framework for sports coaching. Further research should investigate the application of Transformational Leadership to the high-performance netball domain to establish to what extent this framework works in practice.

Whilst the 'Wider sport knowledge' category was not represented within the Characteristics of expertise in this domain, several of the items within other categories (e.g. 'listen to other experts' [24] and 'embrace other experts and support staff' [15]) again suggest our panel acknowledge the importance of boundary crossing to aid coach learning. Furthermore, the Development requirements for this domain are replete with similar processes (see Table 11; e.g. 'conversations with coaches across sports' [2], 'visit other countries and game in action' [5], 'transfer key skills from other areas' [6]). Akkerman and Bakker (2011) describe effectively interpreting information from one context for use in another as an Effort of Translation - a learning mechanism based on collaborative conversations and joint enterprise. The items generated by our panel appear to resonate with this description and so strongly suggest that the theoretical foundation of LoP (Wenger-Trayner \& Wenger-Trayner, 2015) may well provide a useful framework on which the development of expert high-performance netball coaches could be based. Overall, the items are strongly supportive of Côté and Gilbert's (2009) assertion that coaching expertise is constructed through professional, interpersonal and intrapersonal skills - consensus was achieved through several items in each area.

\section{Conclusions}

Characteristics of expertise emerged which were distinct within each coaching domain. This investigation has been the first to gain consensus concerning these characteristics across five domains of netball coaching in the UK. Whilst the consensus of the expert coaches utilised in this study is broadly consistent with the range of research exploring quality coaching practice, distinct characteristics of expertise have been identified in each of the five domains. The domain-specific characteristics of expertise dispute the appropriateness of a one-size-fits-all approach to coach development such as coaching courses which are not tailored to the individual. The distinct characteristics of expertise for each domain are presented in Table 12. 
Table 12. Distinct characteristics of expertise across the five coaching domains

\begin{tabular}{ll}
\hline \hline \multicolumn{1}{c}{ Coaching Domain } & \multicolumn{1}{c}{ Characteristics of expertise } \\
\hline Children & $\begin{array}{l}\text { Prosocial behaviours and positive character traits to development participant confidence. Emphasis } \\
\text { on enjoyable, game-like sessions. Praises effort and asks questions. } \\
\text { Captures attendee's enthusiasm and sustains over the long-term. Transmits energy to } \\
\text { participants, caring, promotes confidence, can break down barriers, adaptable and creative in a } \\
\text { session, welcoming to all participants and can think outside of the box. }\end{array}$ \\
Sustaining participation & $\begin{array}{l}\text { Organised, excellent communication. Encouraging and motivating. Good technical understanding, } \\
\text { excellent planning and knowledge of training methods. }\end{array}$ \\
Performance development & $\begin{array}{l}\text { Knowledge of the performance pathway and elite characteristics, ability to recognise talent and } \\
\text { potential, knowledge of game principles, ability to analyse and read the game, show respect for } \\
\text { individuals, admit one's mistakes and be receptive to change. } \\
\text { High-performance (elite) } \\
\text { Make good decisions under pressure. Ability to plan over the long term, promote quality } \\
\text { performance in coaching, integrate support staff, manage a team, show a strong work ethic, } \\
\text { promote discipline, integrity, transparency, honesty, self-awareness, self-responsibility and be } \\
\text { prepared to listen and learn from others }\end{array}$ \\
\hline \hline
\end{tabular}

Table 13. Summary of the distinct and highest-ranking development requirements across the five domains

\begin{tabular}{ll}
\hline \hline \multicolumn{1}{c}{ Coaching Domain } & \multicolumn{1}{c}{ Development requirements } \\
\hline Children & Reflection, being open-minded, knowledge of self and areas for development. \\
Adult participation & Working with diverse groups, experiential learning and adaptation. \\
Sustaining participation & A range of formal and non-formal education opportunities, mentoring. \\
Performance development & Using athlete feedback, asking questions to the experts and observing elite level coaches \\
High-performance (elite) & $\begin{array}{l}\text { Real life opportunities to develop in competition, be an assistant coach, see netball in other } \\
\text { countries, transfer a range of skills from other life experiences. Must possess intrinsic motives } \\
\text { and commit to develop one's own style. }\end{array}$ \\
\hline \hline
\end{tabular}

Whilst there were some distinctions between the five domains in terms of the development requirements, the differences are best seen when considered alongside the highest ranking items and summarised in Table 13. Overall, the findings demonstrate a strong support for bespoke, predominantly informal coach development journeys incorporating a range of mediated, unmediated and internal learning situations. Consideration of how coaches learn through crossing boundaries and so engaging with environments other than their own warrants further investigation and our findings indicate that the LoP framework may well represent a useful theoretical tool to explore the development of coaches' knowledgeability.

\section{References}

Abraham, A., \& Collins, D. (2011). Taking the next step: Ways forward for coaching science. Quest, 63(4), 366-384.

Abraham, A., Collins, D., \& Martindale, R. (2006). The coaching schematic: Validation through expert coach consensus. Journal of Sports Sciences, 24(6), 549-564. doi:10.1080/02640410500189173

Akkerman, S. F., \& Bakker, A. (2011). Boundary crossing and boundary objects. Review of Educational Research, 81(2), 132-169.

Allan, V., Turnnidge, J., \& Côté, J. (2017). Evaluating approaches to physical literacy through the lens of positive youth development. Quest, 69(4), 515-530.

Allen, J. B., Bell, A., Lynn, A., Taylor, J., \& Lavallee, D. 
(2012). Identifying Excellent Coaching Practice Report. Leeds: National Coaching Foundation.

Allen, J. B., \& Hodge, K. (2006). Fostering a learning environment: Coaches and the motivational climate. International Journal of Sports Science \& Coaching, 1(3), 261-277.

Becker, A. J. (2009). It's not what they do, it's how they do it: Athlete experiences of great coaching. International Journal of Sports Science and Coaching, 4(1), 93-119.

Bengoechea, E. G., Strean, W. B., \& Williams, D. (2004). Understanding and promoting fun in youth sport: coaches' perspectives. Physical Education \& Sport Pedagogy, 9(2), 197-214.

Bertram, R., Culver, D. M., \& Gilbert, W. (2017). A university sport coach community of practice: Using a value creation framework to explore learning and social interactions. International Journal of Sports Science \& Coaching, 12(3), 287-302.

Bertram, R., \& Gilbert, W. (2011). Learning communities as continuing professional development for sport coaches. Journal of Coaching Education, 4(2), 40-61.

Blackett, A. D., Evans, A., \& Piggott, D. (2017). Why the best way of learning to coach the game is playing the game: Conceptualising fast-tracked high-performance coaching pathways. Sport, Education and Society, 22(6), 744-758. doi:10.1080/ 13573322.2015.1075494

Bruner, M. W., Eys, M. A., Wilson, K. S., \& Côté, J. (2014). Group cohesion and positive youth development in team sport athletes. Sport, Exercise, and Performance Psychology, 3(4), 219.

Collins, D., MacNamara, Á., \& Cruickshank, A. (2018). Research and practice in talent identification and development - some thoughts on the state of play. Journal of Applied Sport Psychology, 1-12. doi:10. 1080/10413200.2018.1475430

Côté, J., Bruner, M. W., Erickson, K., Strachan, L., \& Fraser-Thomas, J. (2010). Athlete development and coaching. In J. Lyle \& C. Cushion (Eds.), Sport
Coaching: Professionalism and practice (pp. 63-79). Oxford: Elsevier.

Côté, J., \& Gilbert, W. (2009). An integrative definition of coaching effectiveness and expertise. International Journal of Sports Science and Coaching, 4(3), 307-323. doi:10.1260/174795409789623892

Côté, J., Lidor, R., \& Hackfort, D. (2009). ISSP Position Stand: To sample or to specialise? Seven postulates about youth sport activities that lead to continyed participation and elite performance. International Journal of Sport \& Exercise Psychology, 7(1), 7-17.

Côté, J., Salmela, J. H., Baria, A., \& Russell, S. J. (1993). Organizing and interpreting unstructured qualitative data. Sport Psychologist, 7(2), 127-137.

Côté, J., Salmela, J. H., \& Russell, S. (1995). The knowledge of high-performance gymnastic coaches: Competition and training considerations. The Sport Psychologist, 9(1), 76-95.

Cronin, C., \& Armour, K. (2019). Introduction to care in coaching. In C. Cronin \& K. Armour (Eds.), Care in Sport Coaching: Pedagogical cases. Abingdon: Routledge.

Cronin, C., Walsh, B., Quayle, L., Whittaker, E., \& Whitehead, A. (2018). Carefully supporting autonomy - learning coaching lessons and advancing theory from women's netball in England. Sports Coaching Review, 1-23. doi:10.1080/21640 629.2018 .1429113

Culver, D. M., \& Trudel, P. (2008). Clarifying the concept of communities of practice in sport. International Journal of Sports Science and Coaching, 3(1), 1-10.

Cushion, C. J. (2018). Reflection and reflective practice discourses in coaching: a critical analysis. Sport, Education and Society, 23(1), 82-94. doi:10.1080/ 13573322.2016.1142961

Cushion, C. J., Armour, K. M., \& Jones, R. L. (2006). Locating the coaching process in practice: models 'for' and 'of' coaching. Physical Education \& Sport Pedagogy, 11(1), 83-99.

Denison, J., Mills, J. P., \& Konoval, T. (2017). Sports 
disciplinary legacy and the challenge of 'coaching differently'. Sport, Education and Society, 22(6), 772-783.

Duchesne, C., Bloom, G. A., \& Sabiston, C. M. (2011). Intercollegiate coaches' experiences with elite international athletes in an American sport context. International Journal of Coaching Science, 5(2), 49-68.

England Netball. (2018). Coaching Strategy 2018-2021. Loughborough: England Netball.

English, P., Calder, A., Pearce, S., \& Kirby, K. (2019). A new sporting horizon: a content analysis of Super Netball newspaper coverage. Media International Australia, 171(1), 110-124. doi:10.1177/1329878X 18798696

Erickson, K., Côté, J., \& Fraser-Thomas, J. (2007). Sport Experiences, Milestones, and Educational Activities Associated With High-Performance Coaches' Development. Sport Psychologist, 21(3), 302-316.

Giannarou, L., \& Zervas, E. (2014). Using Delphi technique to build consensus in practice. International Journal of Business Science \& Applied Management (IJBSAM), 9(2), 65-82.

Gilbert, W. D., \& Trudel, P. (2004). Analysis of Coaching Science Research Published from 1970-2001. Research Quarterly for Exercise and Sport, 75(4), 388-399.

Gould, D., \& Carson, S. (2004). Fun and games?: Myths surrounding the role of youth sports in developing Olympic champions. Youth Studies Australia, 23(1), 19-26.

Harvey, S., Cope, E., \& Jones, R. (2016). Developing questioning in game-centred approaches. Journal of Physical Eduction, Recreation and Dance, 87(3), 28-35.

Harvey, S., \& Jarrett, K. (2014). A review of the game-centred approaches to teaching and coaching literature since 2006. Physical Education \& Sport Pedagogy, 19(3), 278-300.

Harvey, S., Lyle, J. W. B., \& Muir, B. (2015). Naturalistic decision making in high performance team sport coaching. International Sport Coaching Journal, 2(2), 152-168.

Harwood, C. G., Knight, C. J., Thrower, S. N., \& Berrow, S. R. (2019). Advancing the study of parental involvement to optimise the psychosocial development and experiences of young athletes. Psychology of Sport and Exercise.

Hodge, K., Henry, G., \& Smith, W. (2014). A case study of excellence in elite sport: Motivational climate in a world champion team. The Sport Psychologist, 28(1), 60-74.

Jones, R. L. (2006). The sports coach as educator: Re-conceptualising sports coaching. London: Routledge.

Jowett, S. (2017). Coaching effectiveness: the coachathlete relationship at its heart. Current Opinion in Psychology, 16, 154-158. doi:10.1016/j.copsyc.2017. 05.006

Keeney, S., Hasson, F., \& McKenna, H. P. (2001). A critical review of the Delphi technique as a research methodology for nursing. International Journal of Nursing Studies, 38(2), 195-200.

Klein, G. (1997). Developing expertise in decision making. Thinking and Reasoning, 3(4), 337-352.

Knowles, Z., Borrie, A., \& Telfer, H. (2005). Towards the reflective sports coach: issues of context, education and application. Ergonomics, 48(11-14), 1711-1720. doi:10.1080/00140130500101288

Lave, J., \& Wenger, E. (1991). Situated Learning: Legitimate peripheral participation. Cambridge: Cambridge University Press.

Light, R. L. (2017). Positive Pedagogy for Sport Coaching: Athlete-centred coaching for individual sports. Abingdon: Routledge.

Lyle, J. (2002). Sports coaching concepts: A framework for coaches' behaviour. London: Routledge.

Lyle, J., \& Cushion, C. J. (2017). Sports coaching concepts: A framework for coaching practice (2nd ed.). Abingdon: Routledge.

Lyle, J., \& Vergeer, I. (2013). Recommendations on the 
methods used to investigate coaches' decision making. In P. Potrac, W. Gilbert, \& J. Denison (Eds.), Routledge Handbook of Sports Coaching (pp. 121-132). Abingdon: Routledge.

Mallett, C. J., Trudel, P., Lyle, J., \& Rynne, S. B. (2009). Formal vs. informal coach education. International Journal of Sports Science \& Coaching, 4(3), 325334. doi:10.1260/174795409789623883

Moon, J. A. (2004). A Handbook of Reflective and Experiential Learning: Theory and practice. Abingdon: Routledge.

Morley, D., Morgan, G., McKenna, J., \& Nicholls, A. R. (2014). Developmental contexts and features of elite academy football players: coach and player perspectives. International Journal of Sports Science \& Coaching, 9(1), 217-232.

Nash, C., \& Collins, D. (2006). Tacit knowledge in expert coaching: Science or art? Quest, 58(4), 465477.

Nash, C., Martindale, R., Collins, D., \& Martindale, A. (2012). Parameterising expertise in coaching: Past, present and future. Journal of Sports Sciences, 30(10), 985-994. doi:10.1080/02640414.2012.682079

Nash, C., \& Sproule, J. (2011). Insights into experiences: Reflections of an expert and novice coach. International Journal of Sports Science and Coaching, 6(1), 149-162.

Nash, C., Sproule, J., \& Horton, P. (2017). Continuing professional development for sports coaches: a road less travelled. Sport in Society, 20(12), 1902-1916. doi:10.1080/17430437.2017.1232414

Nelson, L. J., Cushion, C. J., Potrac, P., \& Groom, R. (2014). Carl Rogers, learning and educational practice: Critical considerations and applications in sports coaching. Sport, Education and Society, 19(5), 513-531.

Nojima, Y., Tomikawa, T., Makabe, S., \& Snyder, M. (2003). Defining characteristics of expertise in Japanese clinical nursing using the Delphi technique. Nursing \& Health Sciences, 5(1), 3-11.

Occhino, J. L., Mallett, C. J., Rynne, S. B., \& Carlisle, K.
N. (2014). Autonomy-supportive pedagogical approach to sports coaching: Research, challenges and opportunities. International Journal of Sports Science \& Coaching, 9(2), 401-416.

Piggott, D. (2012). Coaches' experiences of formal coach education: a critical sociological investigation. Sport, Education and Society, 17(4), 535-554. doi:10.1080/13573322.2011.608949

Reneker, J. C., Clay Moughiman, M., \& Cook, C. E. (2014). The diagnostic utility of clinical tests for differentiating between cervicogenic and other causes of dizziness after a sports-related concussion: An international Delphi study. Journal of Science and Medicine in Sport, 18(4), 366-372. doi:10.1016/j.jsams.2014.05.002

Robertson, H. A., \& MacKinnon, N. J. (2002). Development of a list of consensus-approved clinical indicators of preventable drug-related morbidity in older adults. Clinical Therapeutics, 24(10), 1595-1613. doi:10.1016/S0149-2918(02)8 0063-7

Robertson, S., Kremer, P., Aisbett, B., Tran, J., \& Cerin, E. (2017). Consensus on measurement properties and feasibility of performance tests for the exercise and sport sciences: a Delphi study. Sports Medicine - Open, 3(1), 1-10. doi:10.1186/s40798-016-0071-y

Scanlan, T. K., Ravizza, K., \& Stein, G. L. (1989). An in-depth study of former elite figure skaters: I. Introduction to the project. Journal of Sport and Exercise Psychology, 11(1), 54-64. doi:10.1123/jsep. 11.1.54

Schempp, P., McCullick, B., \& Mason, I. S. (2006). The development of expert coaching. In R. Jones (Ed.), The sports coach as educator: Re-conceptualising sports coaching (pp. 145-161). Abingdon: Routledge.

Schön, D. A. (1987). Educating the Reflective Practitioner. San Francisco: Jossey-Bass.

Smith, J. A. (2004). Reflecting on the development of interpretative phenomenological analysis and its contribution to qualitative research in psychology. Qualitative research in psychology, 1(1), 39-54. 
Smith, R. E., Smoll, F. L., \& Cumming, S. P. (2009). Motivational climate and changes in young athletes' achievement goal orientations. Motivation and emotion, 33(2), 173-183.

Sport England. (2016a). Active People Survey 10. London: Sport England.

Sport England. (2016b). Coaching in an active nation: The coaching plan for England 2017-2021. London: Sport England.

Stoszkowski, J., \& Collins, D. (2016). Sources, topics and use of knowledge by coaches. Journal of Sports Sciences, 34(9), 794-802.

Strachan, L., Côté, J., \& Deakin, J. (2011). A new view: exploring positive youth development in elite sport contexts. Qualitative Research in Sport, Exercise and Health, 3(1), 9-32. doi:10.1080/19398441.2010. 541483

Taylor, B., \& Garratt, D. (2010a). The professionalisation of sports coaching: definitions, challenges and critiques. In J. Lyle \& C. Cushion (Eds.), Sports coaching: Professionalisation and practice (pp. 99-117). London: Churchill Livingstone.

Taylor, B., \& Garratt, D. (2010b). The professionalisation of sports coaching: Relations of power, resistance and compliance. Sport, Education and Society, 15(1), 121-139.

Trudel, P., \& Gilbert, W. (2013). The role of deliberate practice in becoming an expert coach: Part 3 creating optimal settings. Olympic Coach Magazine, 24(2), 15-27.

Turnnidge, J., \& Côté, J. (2018). Applying transformational leadership theory to coaching research in youth sport: A systematic literature review. International Journal of Sport and Exercise Psychology, 16(3), 327-342. doi:10.1080/1612197X. 2016.1189948

Vergeer, I., \& Lyle, J. (2009). Coaching experience: Examining its role in coaches' decision making.
International Journal of Sport and Exercise Psychology, 7(4), 431-449.

Vierimaa, M., Erickson, K., Côté, J., \& Gilbert, W. (2012). Positive youth development: A measurement framework for sport. International Journal of Sports Science \& Coaching, 7(3), 601-614.

Vinson, D., \& Bell, J. (2020). Athlete-centred coaching: An applied example from junior international field hockey. In E. Cope \& M. Partington (Eds.), Sports Coaching: A theoretical and practical guide (pp. 40-52). Abingdon: Routledge.

Vinson, D., Brady, A., Moreland, B., \& Judge, N. (2016). Exploring coach behaviours, session contexts and key stakeholder perceptions of non-linear coaching approaches in youth sport. International Journal of Sports Science and Coaching, 11(1), 54-68.

Wenger-Trayner, E., \& Wenger-Trayner, B. (2015). Learning in a landscape of practice: A framework. In E. Wenger-Trayner, M. Fenton-O'Creevy, S. Hutchinson, C. Kubiak, \& B. Wenger-Trayner (Eds.), Learning in Landscapes of Practice (pp. 13-29). Abingdon: Routledge.

Wenger, E. (1999). Communities of Practice: Learning, meaning, and identity. Cambridge: Cambridge University Press.

Werthner, P., \& Trudel, P. (2006). A new theoretical perspective for understanding how coaches learn to coach. The Sport Psychologist, 20(2), 198-212.

Werthner, P., \& Trudel, P. (2009). Investigating the idiosyncratic learning paths of elite Canadian coaches. International Journal of Sports Science and Coaching, 4(3), 433-449.

Zimmerman, B. J. (2005). Attaining self-regulation: A social cognitive perspective. In M. Boekaerts, P. R. Pintrich, \& M. Zeidner (Eds.), Handbook of self-regulation (pp. 13-42). San Diego, CA: Academic Press. 